UNIVERSITY OF CHITRAL JOURNAL OF LINGUISTICS AND LITERATURE

VOL. 5 | ISSUE II | JULY - DEC | 2021

ISSN (E): 2663-1512, ISSN (P): 2617-3611

https://doi.org/10.33195/ill.v5ill.339

\title{
Postcolonialism, Liberal Internationalism, 9/11 and Pakistani English Fiction
}

\author{
Bushra Naz \\ Assistant Professor, Department of English Literature \\ IUB, Bahawalpur, Pakistan
}

\begin{abstract}
In this article I argue that Momo, Chengaze, and Daanish's quest of political liberty and identity in Red Birds, The Reluctant Fundamentalist and Trespassing respectively manifests that liberal-internationalism is a colonial agenda. Focussing on the development of liberal internationalism because of the transformation of the colonial to a neo-colonial strategy of the powerful countries, I argue that Pakistani fiction demonstrates these policies influencing and affecting everyday life of ordinary Muslims living in refugee camps, diaspora or in Pakistan. Focal point would be the examination of the procedures and constituents of the liberalinternationalism to distinguish colonial subterfuges and ruses of upholding control in the erstwhile and contemporaneous colonies exemplified in these novels in the context of post 9/11. For the purpose of this analysis, I have taken Chris Brown and Kristen Ainley's notion of liberal internationalism as a modern means of colonization, Gilbert Rist's ideas of liberal internationalism as a medium of disguised colonization and E. H. Carr's view of the internationalism as a utopian fantasy for fundamentally being a colonial economic agenda to keep afloat the conflict between 'haves' and 'have not' by way of creating an economic dependency of the third world nations' upon the rich nations. Following this, I will interpret Brown, Ainley and Rist's philosophy of the production of liberal internationalism as a secreted ploy of modern colonization building on Carr's notion of international liberalism as a paradox of political and economic freedom and a disagreement against it for political and economic liberty, an essential element in M. Hanif, Mohsin Hamid, and Uzma Aslam Khan's protagonist's achievement of individual sovereignty through a fundamental reconceptualization of their identity to the decolonization of their personhood.
\end{abstract}

Keywords: Postcolonialism, Liberal Internationalism, 9/11, War on Terror, Identity

\section{Introduction}

In this essay I argue that Momo, Chengaze, and Daanish's quest of political liberty and identity in Red Birds, The Reluctant Fundamentalist and Trespassing respectively manifests that liberal-internationalism is a colonial agenda. Focussing on the development of liberal internationalism as a result of the transformation of the colonial to a neo-colonial strategy of the powerful countries, I argue that Pakistani fiction demonstrates these policies influencing and affecting everyday life of ordinary Muslims living in refugee camps, diaspora or in Pakistan. Focal point would be the examination of the procedures and constituents of the liberal internationalism to distinguish colonial subterfuges and ruses of upholding control in the 
erstwhile and contemporaneous colonies exemplified in these novels in the context of post 9/11. For the purpose of this analysis, I have taken Chris Brown and Kristen Ainley's notion of liberal internationalism as a modern means of colonization, Gilbert Rist's ideas of liberal internationalism as a medium of disguised colonization and E. H. Carr's view of the internationalism as a utopian fantasy for fundamentally being a colonial economic agenda to keep afloat the conflict between 'haves' and 'have not' by way of creating an economic dependency of the third world nations' upon the rich nations. Following this, I will interpret Brown, Ainley and Rist's philosophy of the production of liberal internationalism as a secreted ploy of modern colonization building on Carr's notion of international liberalism as a paradox of political and economic freedom and a disagreement against it for political and economic liberty, an essential element in M. Hanif, Mohsin Hamid, and Uzma Aslam Khan's protagonist's achievement of individual sovereignty through a fundamental reconceptualization of their identity to the decolonization of their personhood.

\section{Literature Review}

Ali Usman Saleem perceives post 9/11 Western discourses on war on terror in the historical context of postcolonialism. Discussing the background of Pakistan's constant engagement with the wars in British colonial rule in Afghanistan and Pakistan's northern areas, Saleem argues that it has resulted in an unstable political culture and fragmentation of the society. Saleem argues that Pakistani 9/11 fiction responds to Western discourses of war on terror in relation to Pakistan keeping in view the incursion of the USA in Afghanistan, Saleemi points to the dominating role of the USA film and media in the construction of the discourse of religious extremism, social decadence and political debauchery in the international politics of Pakistan (Saleem, 2015). Pointing to a radical shift in the writings of Pakistani authors, Saleem proposes that their fiction offers a forceful commentary on international and native culture of politics by providing a national perspective on various these issues and question the international intervention by portraying them in big picture. Situating his argument in the perspective of the conflict of Islamic the Western philosophies on the war on terror, Saleem puts forward that the Pakistani fiction enlightens the international reader not only on the indigenous socio-political, cultural crisis, misuse and manipulation of religious discourse and draws their attention to the political profligacy and moral dissolution of the Pakistani political 
elite and the dubious financial and fraudulent activities of the power institutions in tandem these writings present Pakistan as a progressive, forbearing and tolerant state yet caught in the international western manipulations of the idea of terrorism thus is in wretched suffering politically (Saleem, 2015). Saleem further argues that through their narratives, these writers have contested the western hegemonic discourse of anti-Pakistan for assisting Taliban, religious extremists, militant groups and organizations (Saleem, 2015). Saleem goes on to add that through their narratives these writers have used the former colonial culture in current postcolonial Pakistani literature to explore and deconstruct its "national history to find reasons for the current socio-political and economic crisis" (Saleem, 2015, p. 3). Saleem argues that these writings ignore the traditional postcolonial ideas and observe contemporary international socio-political and cultural phenomenon involving an exchange of a dialogue with the western reader on Pakistan and the Muslim world (Saleem, 2015) to decolonize their identity West has created after $9 / 11$.

On the other hand, Shazia Sadaf argues for the employment of the lens of human rights in the post 9/11 scenario to understand the dilemma of identity presented in the Pakistani fiction in the context of the "neo-imperialism, global mistrust, and human suffering" (Sadaf, 2017, p. 1). Insisting upon the importance of human right aspect in teaching Pakistani Anglophone fiction, Sadaf emphasizes that this is how Western discourse of war on terror and terrorism can be contested. She argues for a comprehensive contextualization of current Anglophone Pakistani literature within the subcontinental history of British colonization to draw important insights in to the contemporary human rights debates in the post 9/11 period and exemplifies this equivocal and incongruous logic of the human rights universalism of the exclusion of the enemies from the identical human rights through legal system and codification by drawing upon Agamben's conception of the "states of exception" which recognizes these enemies not in terms of human beings or citizen rather subjects not only during the era of British empire but also in recent US war on terror (Sadaf, 2017). Taking a view of the European colonial history of interventions, Sadaf refers to cultural relativists and pluralists to recoursing on colonial historicity to contest the "United Nations international human rights norm that are seen to be "Western oriented and not adequately reflective of non-Western perspectives" (Sadaf, 2017, 4). Referring to culturalists comparisons of the eighteenth and nineteenth century colonialism with human rights and contemporary USA hegemony, Sadaf upholds that 
Eurocentric colonial projects promoted the monolithic view of their superiority and goes on to say referring to Ibhowah that the USA military operations in Middle East and Gulf after 9/11are codified as freedom missions and this policy underlines the foregrounding of postcolonial logic about human rights dialogue and challenges the thesis of the universality of the human rights established and imposed by the colonial empires (Sadaf, 2017).

To conclude, Saleem's idea of the war on terror as a continuity of neo colonial project and Sadaf's notion of the human rights violation in the name of the war on terror provides me space to reconceptualise Momo, Chengaze and Daanish's struggle to get a socio-political autonomy in Red Birds, The Reluctant Fundamentalist and Trespassing respectively in a comprehensive theoretical framework of the colonial, neo colonial institutions and the policies of liberal internationalism and struggle of their autonomy as a representation of their resistance to acknowledge the universalism of Muslim identities in enemies of the west.

\section{Theoretical Contexts}

\section{Liberal-Internationalism and Colonial Legacies}

Setting a limit of this debate article, I will focus on the procedures and policies of liberal internationalism that emerged after the plight of the First World War when it became inevitable for the European and American to ascertain and launch new ideology of international relations to deal with this political crisis. To transcend this destruction "covenants" (Chris Brown and Kristen Ainley, 2009, p. 20) being the major source was opted by the European and America for liberal internationalism as the new policy for international political relations. To transcend the horrors of the war liberal-internationalist created propaganda of the avoidance of the war by sponsoring and subsidising liberal democracies generally and particularly against military regimes and autocracies in the third world. To operate this ideology USA manufactured the existence of the League of Nations (Brown and Ainley, 2009) to mechanize and regulate international relations between and among superpowers and their vanquished territories. The permanent Mandates Commission granted League associates executive authority to claim territorial control of these colonies for being available (Gilbert Rist, 2008) space in need of new rulers. To Rist, occupation of the new territories was not in its sphere and affair rather it functions to legitimate the globalization of political infringement and intervention (Rist, 2008) to satisfy predetermined political interests in the name of nationalism. The wresting of Iraq, 
Palestine, and Jordan can be seen as the consolidation of the rule of the British Empire (Rist, 2008) besides, the control of France on Labanon and Syria. In tandem, USA foregrounded her hegemony through an open-door policy for free trade by granting free ingress to the powerful nations in the subject lands. Recognizing these economic policies as blanketed procedures (Rist, 2008) of colonization to foreground its legitimacy for being the part of the League of Nations, Rist asserts that though USA opposed direct formal colonization through territorial control but made her contravention possible through the agency of League thereby institutionalizing the colonial intervention in the third world nations. Dismissing liberal internationalism as a utopia (E. H. Carr, 2001), H. E. Carr critiques it as a contrived fantasy to masquerade factual matters of disagreements and clash as territorial control was not enough to justify their administration of the land obtained under duress. Drawing upon Carr's idea of liberal international as a political fancy, Brown and Ainley explain that the real conflict of the colonizer and colonized is foregrounded in the fact of the "haves" and "have-nots" (Brown and Ainley, 2009, p. 25) liberal internationalism is a colonial manoeuvre to serve the interests of the powerful nations. The United Nations owes its existence to the League of Nations. Building United Nations, the main goal of the League was to develop an international political hierarchy of national organizations to guard national aims. Contextualizing Carr's idea of the dichotomy of 'have' and 'have not' Carr, 2001), I analyse the procedures and methods of colonization ingrained in the liberal internationalism. Launching invasions against third world countries using "military intervention" side by side offering "appeasement" (Brown and Ainley, 2009, p. 24) avenues to the United Nations member countries, Brown perceives it as a "rebranding" (Brown and Ainley, 2009, p. 27) of the past colonial projects of the empire.

\section{Red Bird, The Reluctant Fundamentalist, Trespassing and the Post-War Liberal Internationalism and Development}

The founding principle of liberal internationalism is grounded in the theory of "development" (Rist, 2008, p. 76) given in the Covenant of the League formerly and now "underdevelopment" exploited by UN. In Red Birds, the Camp portrays insufficiency and dispossession as it exudes neglect and lack for humanism. It is a "camp without water taps, a camp with road tax, a camp without a road, a camp with electric poles, a camp without electricity...a camp without a boundary wall" (Hanif, 2018, p. 13). Being run by a "evil entrepreneur, a post war profiteer, a petty black marketer" (Hanif, 2018, p. 17) like Momo, the 
Camp dwellers despite of being so poor "live in UN tents, eat exotic food donated by USAID and burp after drinking fizzy drinks". Ellie justifies American "interventions" in the local market with the rationale that "You can't give them drip irrigation and tent school and hope for them to become civilized...give these men on camelbacks rocket launchers and see them arrive in the new millennium...They don't even need an ideology" (Hanif, 2018, p. 33). Ellie considers these "mad bloody Arabs" (Hanif, 2018, p. 59) as "a third-world militia...enemy" (Hanif, 2018, p. 76) living in the "corrugated blue plastic roofs, stretching like a low, filthy sky, broken by piles of grey plastic poles and overflowing blue plastic rubbish bins (Hanif, 2018, p. 92) and a "shithole" being taken care by Father Dear as its "storekeeper" (Hanif, 2018, pp. 108-9). Although they "eat USAID grains, get USAID injections" idealize "Disneyland" (Hanif, 2018, p. 110) yet they are politically impassive and nonbeing as Edward Said claims that the "new Imperialism" caused, prodded, pressed, and imposed a responsibility upon the natives to activate their passive Orient being into militant modern life (Said, 2003, p. 241). Rist identifies that contemporary international relations were based on anti-colonial imperialism. This meant that the already established colonies of the world would now be colonised in a new manner. Mutt's objection on the arrival of the foreign intruders in the Camp recalls the old colonial subterfuges when "[b]ig, rich nations [would] get a bloody nose in far-off countries and start slashing the milk honey for poor babies at home" (Hanif, 2018, p. 25) to which attaching an inexorable historicity of imperialism, Ellie observes the native as intrinsically "evil" and "barbarians" (Hanif, 2018, pp. 197-199) in the imagination of empire. Ellie's description of the outfits of the children in European police paramilitaries, teenagers in NATO general uniforms, grandfathers wearing British infantry overall and teenage girls wearing berets' of French Foreign Legion informs this imperial historicity. In The Reluctant Fundamentalist, meeting in Anar Kali, Changez informs the foreigner the historical importance of Lahore and suddenly jumps at famous horror Hollywood movie by inquiring "Are you familiar with The Legend of Sleepy Hollow" (Hamid, 2019, p. 103) as if describing the abode of an apathetic, indolent, and passive colonized.

To decolonize the former colonization of the British Empire a new procedure was devised by the international political forces whereby U.S. patronized and organized access to 
new "markets" (Rist, 2008, p.75). Red Birds exemplifies it in terms of "ghosts" army installations and "currency... cheque book" to perform "military operations" (Hanif, 2018, pp. 174-176). Ellie has a "65-million-dollar machine to fly, with the smartest bomb" which is more like a "three star hotel" to make "perfect landing" (Hanif, 2018, pp. 3-5) in this "big, bad world" living on "strange lands" (Hanif, 2018, pp. 213-227) not to justify the ways of God to men rather to introduce American warfare technology as "museum pieces" and to endow these poor nations the technique of "one-handed war" which they could launch with "remote controls drones" (Hanif, 2018, p. 5) to wage war against a "devastated Third World dictatorship on thoroughly ideological grounds" (Said, 2003, p. xv). Ellie believes in war as an "opportunity" (Hanif, 2018, p. 5) to diagnose the malaise the "young Muslim mind is subjected to" (Hanif, 2018, p. 171) with a Doctor who "wears the blue overalls of a US Army infantry sergeant complete with stripes and standard-issue Ray-Bans, held together with Scotch tape and a USAF helmet with WE DARE emblazoned on it" (Hanif, 2018, p. 172) to rehabilitate them from oppression. With F15 Strike Eagle, and M16s, Ellie is the agent of a superpower who operates as the "liberator" of the "third-world countries" (Hanif, 2018, p. 272). In this perspective, elucidating the role of empire in the third world Said explains "what imperialism has done,... Think of the line that starts with Napoleon, continues with the rise of Oriental studies and the takeover of North Africa, and goes on in similar undertakings in Vietnam, in Egypt, in Palestine and, during the entire twentieth century, in the struggle over oil and strategic control in the Gulf, in Iraq, Syria, Palestine and Afghanistan" (Said, 2003, p. Xviii). The Reluctant Fundamentalist unravels this mystery of American imperialism when Chengaze shares his feelings with the American role in the politics of the third world in following words that "Vietnam, Korea, the straits of Taiwan, the Middle East, and now Afghanistan: in each of the major conflicts and standoffs that ringed my mother continent of Asia, America played a central role" (Hamid, 2019, p. 96). Comparing the past transaction of three-way affair of Soviet arms through Egypt, technological and financial assistance by USA and provision for training camps by Pakistan, Shamsie perceives an multinational and collaborative economic agenda behind gulf war and explains this three way activity in the contemporary political setting that now war is an international affair involving Egypt, China, Israel, Muslims from all over the world and international capitalism (Shamsie, 2009). 
This new strategy to subvert old British imperialism was based on premise of "development" and "underdevelopment" (Rist, 2008, p. 60). In Red Birds, Momo perceives Lady Flowerbody's research work to redress the "miserable existence" (Hanif, 2018, p. 24) of these natives philosophically and intellectually and her co-worker the Dear Father, a local bourgeoisie to coalesce the local and international nexus owes their privileged position to centrist monopolies as "this place may look poorer than Afghanistan and more violent then Sudan but thank God there is no ideology at stake. Not for them, not for us" (Hanif, 2018, p. 65). Momo insists that these foreigners have not come here to take "three thousand litres of contaminated water...[or] conquering some big castle" but to "bomb us because they assume we are related to bad Arabs" (Hanif, 2018, p. 65). Momo emphasizes that these "capitalists" consider them "primitive" (Hanif, 2018, p. 127) "history's burden" (Hanif, 2018, pp. 127-131) and "animal" living in caves and need new master to tame them. As per development theory nations after wars have becomes weak have "strenuous conditions of the modern world" hence require advanced and developed nations' "tutelage" (Rist, 2008, p. 60) to stand by themselves. In this light, Lady Flowerbody's research upon "Teenage Muslim Mind" and to exploit this "community as a laboratory" (Hanif, 2018, p. 44) to analyze their "suppressed violent fantasies" their "suffering" and an inexorable "delirium", of "sinners and salvation" (Hanif, 2018, pp. 116-117) as her "lab rat" paradoxically documents her appetitive "designs" (Hanif, 2018, p. 135) instead of scrutinizing the raison d'être of the "global plight of the young Muslim" (Hanif, 2018, p.181) in terms of their lack of education, paucity, and "starving...children" (Hanif, 2018, p. 245). As McClennen and Moore highlight the violation of the human rights in this war on terror by arguing that it is important that while looking at 9/11 fiction special consideration should be given to the "blatant violations of the rights of Afghans, Iraqis, and Palestinians... with the official rhetoric of the United Nations, nongovernmental organizations, and the White House?" (McClennen and Moore, 2016, pp. 3-5). Similar to Said's notion that to "colonize meant at first the identification —indeed, the creation — of interests; these could be commercial, communicational, religious, military, cultural" (Said, 2003, p.101). Chengaze in The Reluctant Fundamentalist informs this notion by reflecting upon American policies of war on terror as the fulfilment of an empire's interests "Moreover, I knew from my experience as a Pakistani - of alternating periods of American aid and sanctions - that finance was a primary means by which the American empire exercised its power (Hamid, 2019, p. 96). To Chengaze 
a common plea to unify these conflicts through the advancement of a coterie vision of American led policies of war against terrorism based on organized and political massacre of the masses by uniformed mercenary forces corresponds to the "killers" living in those lands for these mercenary forces hence signify "collateral damage" and adds "America felt justified in bringing so many deaths to Afghanistan and Iraq, and why America felt justified in risking so many more deaths by tacitly using India to pressure Pakistan" (Hamid, 2019, p. 108). In Trespassing when Daanish informs Beky Floe about his father who is a doctor she shows her awe for a third world immigrant when she says "So, did you grow up in, like, a palace or something?' 'Oh no,' he laughed, 'my father's a doctor.' She eyed him quizzically, as if unable to believe the Third World had doctors" (Khan, 2013, p. 31). In this regard, Spivak argues that master develops the discourse of the colonized's "depravity", "treachery", "brutality" and "perfidy", to set up its need to submit to the empire as an "obligation" (Spivak, 1985, pp. 25455) to its "anticipated mastery" (Lacan, 1968).

The "U.S. hegemony" (Rist, 2008, p. 75) hinges upon the policy of development and underdevelopment to which Rist explains as an apparatus of keeping a link with the "Third World" to intrude and to redress their hunger, diseases, poverty etc. This also means to say that it allows the powerful states to revisit their civilization mission under human rights, moral disciplining, and social wellbeing of these poor nations as the universalism of such norms is the underpinning logic of liberal internationalism thereby identifying the dependency of the poor nations upon the rich. In Red Birds when local and international "smuggler[s]...hoarder[s] and...black marketer[s]" in global "business...merchandise" (Hanif, 2018, p. 18) do not fail Momo for his relentless profit making desire as he believes by taking "Bigger risks, bigger returns" (Hanif, 2018, p. 19) can be attained from the "international-aid types" (Hanif, 2018, p. 19) programmes to satisfy his need. Regarding Lady Flowerbody's claim that the "process of rehabilitation can't start till we recognize our losses", Momo recognizes it as a "honey trap" (Hanif, 2018, pp. 47, 46) of the imperial "dealers" (Hanif, 2018, p. 26) to extract information to establish control upon the Camp. Ellie's statement that their "one-sided wars would have become boring by now. But they still keep at it" to endow technological and "industrial" (Hanif, 2018 , p. 160) potency to the third world nations but also as Ellie identifies poor nations dependency upon them when he says, "We're fighting this war and the previous war and the ones budgeted for next year in order to bring some of these freedoms to the other parts of the 
world" (Hanif, 2018, p. 161). Extolling Lady Flowerbody's academic mission as a collaborative effort to mortgage democracy to the poor oppressed nations, Ellie's words unfold his neoliberal agenda of the mysterious enslavement of the third world when he reflects as to how this cycle of dependency and free market coalesce and works as places are bombed to be rescued, fire is rained to be extinguished and babies to be saved, people are made homeless to be provided shelter, cities are obliterated to be rebuilt, to demonstrate advanced nations empathy for the war torn territories and people, to exhibit unison for the 'have nots' picture galleries are run in Berlin, and fundraising balls are arranged in London. Said asserts the paradox of the "American power to construct there an ersatz model of free market "democracy"” (Said, 2003, xv) promotes an "appetite for weapons" (Hanif, 2018, p. 222) to obtain "security" (Hanif, 2018, p. 227). In this regard, T. Dos Santos definition of dependence as a "conditioning situation" (T. Dos Santos, 2001, p. 76) whereby the economies of one faction of states are stipulated upon the expansion and extension of the other faction of nations pertinent to understand the idea of the economy of the first and third world nations. In this context "United Nations teary eyes" (Hanif, 2018, p. 25) formulate Bro Ali as a "victim" of "collateral damage" (Hanif, 2018, p. 136) to which Mutt receives as an irony of the notion of global security when he reflects that global security is the social engineering by creating job opportunities whereby facilities are built, empowered by workforce, extended by the deployment of guards to secure the security system, finally destroyed by hired labour with sanctioned reconstruction contracts (Hanif, 2018, p. 231). In this background, The Reluctant Fundamentalist underscores the domination of American dollar in the international market when Chengaze mentions the importance of "American Express" (Hamid, 2019, p. 24) and compares his income in Pakistan when he sends "money" (Hamid, 2019, p. 97) to his brother. Arguing that postcoloniality is a value-regulating apparatus within the global late-capitalist organization of goods exchange, Huggan explains that the colonial discourse is "subservient to global capitalist economy...by which generalized cultural differences are manufactured, disseminated and consumed" (Huggan, 2001, pp. 9-10).Vladimir Lenin maintains that "imperialism is the monopoly stage of capitalism" (V.I. Lenin, 2004, p. 88) and world's economic system is a juncture of evolution from a "colonial policy" (Lenin, 2004, p. 89), extended to a neo-colonial policy of monopolists thereby completely dividing the ownership of the world in territorial compartments. According to Frank's approach, colonial empires first 
created colonies, employed their capitalist systems subsequently with the emergence of the new empires capitalists vested interests evolved and changed under new organizational and institutionalized regimes of U.N and the same colonized terrains further divided and went under the exploitation of the "advanced nations", (Rist, 2008, p. 60). In The Reluctant Fundamentalist Chengaze observes post 9/11 New York and endorses the emergence and realization of American imperialism in its full force to the American stranger that "Other reproaches were far louder. Your country's flag invaded New York after the attacks; it was everywhere. Small flags stuck on toothpicks featured in the shrines; stickers of flags adorned windshields and windows; large flags fluttered from buildings. They all seemed to proclaim: We are America — not New York, which, in my opinion, means something quite different - the mightiest civilization the world has ever known; you have slighted us; beware our wrath. Gazing up at the soaring towers of the city, I wondered what manner of host would sally forth from so grand a castle" (Hamid, 2019, p. 47). Trespassing divulges this American imperialism as a relentless unilateral force of othering of the rest of the world when on his way to Karachi Daanish is held in the plane at Frankfurt and is not allowed to disembark with many other passengers for not holding American passport that "Only those ladies and gentlemen holding American, Canadian, or European passports could disembark for the duration of the stopover. Those naughty others might escape, so they must stay on board” (Khan, 2013, p. 26).

One aspect of the concept of the development is poor nations' dependency upon the "star" and "satellite" technology (Andre Gunder Frank, 1969, p. 3) of the modern states. This not only elides to an inherent inequality but also explains the economic exploitation of the poor countries in the "international system" (T. Dos Santos, 2001, p. 75) for being needy and insecure. The constant mention of "Nat Geo Xtra and Capital Talk" (Hanif, 2018, 16) and Momo's aspirations for profits as he says "I have seen people on Nat Geo Late Night who make so much money through drugs that they are called narcobarons" (Hanif, 2018,150) substantiates as to how this satellite exploitation and interdependency operates in a colonial manner. For Momo, to keep the "surveillance" on the Camp is not to encounter any threat rather “information is the new oil" (Hanif, 2018, 167). Similarly Foucault suggests an inevitable and unrelenting association between knowledge and power as through its infinitesimal apparatus 
which has its own history, trajectory, techniques, planning and procedures, power hierarchies are "invested, colonized, utilized, involuted, transformed, displaced, extended, etc. by ever more general mechanisms and by forms of global domination" (Foucault, 1972, p. 159). The Hanger operates as an "American base", "protected [by] an electrical mechanism, which monitors the potential intruders, petty ...ambitious thieves" (Hanif, 2018, p. 194) through “miles and miles of razor wire...saying IT'S NOT A THOROUGHFARE, INTRUDERS WILL BE SHOT, THIS PROPERTY IS PROTECTED BY GUARD DOGS” and any foray from the Camp in the Hanger is considered as "an act of treason" (Hanif, 2018, 195). In The Reluctant Fundamentalist Chengaze's description of the American occupation of Afghanistan after $9 / 11$ on the American media to the American stranger substantiates that America espoused political control through cultural hegemony through information technology, mass communication, mass production and mass consumption. As Chengaze admires American technological supremacy in terms of his obsession with "Star Trek", "Microsoft Family Time", and "Star Wars" (Hamid, 2019, pp. 7, 22-3). Providing a description of Afghanistan war in the perspective Checgaze reflects that how he was avoiding "to watch the partisan and sportsevent-like coverage given to the mismatch between the American bombers with their twentyfirst-century weaponry and the ill-equipped and ill-fed Afghan tribesmen below" (Hamid, 2019, p. 59). Chegaze finds himself enmeshed in politics and history when he finds himself confronted by American "programming" of the 9/11 reasons while sitting in "cable company's offices" or film "Terminator" with the revered roles whereby the machines are serving the purpose of heroes (Hamid, 2019, p. 59). In this regard discussing the power of media in the construction of western discourse against Islam, Singh argues through decrepitude figure, Islamic, turbaned, non western, bearded, radical jihadi is portrayed in media to invoke the ideas of "illiteracy, fundamentalism, hatred, and violence, this figure is rearticulated through postcolonial fiction to produce the disempowered refugee, the disenchanted immigrant, and the dissident citizen" (Singh, 2012, p. 174). Similarly, when Daanish in Trespassing finds a letter from Marine in a medical journal about the Americans in the Gulf War he becomes surprised to see the global monopoly of American war industry and their media was presenting the celebrated picture of the American Brand militant intrusion as an upright country against the terrorist Iraq instead of offering Gulf War as a media hype as one of the World Wide famed American products (Khan, 2013). Discussing the significance of the news channels to keep this 
dichotomy as a clash of the East and the West, Said argues the warmongering expertise of the “omnipresent CNNs and Foxs of this world" (Said, 2003, p. Xvi).

One of the feature of "colonial export economy" (Santos, 2001, p. 77) is embedded in the development of the mercantile system of capitalism whereby poor countries buy the finish product of their own raw material at a high cost thereby remain disadvantaged, dependent and economically depraved. As the export of the raw material and the import of the finished product of this country is mediated by a bourgeoisie class hence it monopolizes middleman and comprador's interests. To put in other words it is one of the means of the exploitation of the poor states. As the "Father Dear became Mr. Fix It for the people at the Hangar their logistics man, their local guy" (Hanif, 2018, pp. 27-8). Even to secure "compensation" and "pay[ment]" (Hanif, 2018, p. 99) for the lost employment he "sold" his son to the Hanger. The Father Dear's "series of transactions" his "files...paperwork" (Hanif, 2018, pp. 101-4) upholds him a "local logistic officer for USAID" who bargains with the foreign "visitor" the "prospects" (Hanif, 2018, p. 107) of the Camp for future transaction. At this "military installation" (Hanif, 2018, p. 181) apart from the Father Dear, Ellie states that Lady Flowerbody "was my traffic controller, my direction finder, my navigation map...we complete each other" (Hanif, 2018, p. 200) to whom Mutt observes as a source of capital currency in the international academic and economic terms for extracting "American sponsored researchers" to make money even out of sand and birds (Hanif, 2018, p. 86). In The Reluctant Fundamentalist as admiring "The Great Gatsby" (Hamid, 2019, p. 26), Chengaze finds himself enmeshed in the choice of the ideal business model, when Jim says to Chengaze in the context of the Underwood Samson policy of the laying off and recruitment of the workers that the "economy's an animal" (Hamid, 2019, p. 58) as if to say business has nothing to do with humanism and human life and dignity. In this regard, Ilana Gershon argues that "neoliberalism has been globally successful as an “encompassing hegemonic project"”' (Gershon, 2011, p. 537).

Liberal internationalism in contemporary politics demonstrates itself in American “emergency package" (David McNally, 2006, p. 243) which David McNally perceives as an 
intervention ploy to let business corporations launch trafficking of military weapons, drug, oil, and buying of private property to extend control as few of the illustrative examples for free market access and open door policy in the present international scenario which can be compared in the establishment of the East India Company. In Red Birds, Momo believes that to work in the "real estate" through "mercenary" (Hanif, 2018, p. 170) forces will be profitable and safe. It made land "alienable" (Krishna, 2008, p. 245). Karl Marx argument explains that "settler" (Marx, 1920, p. 794) processes this ingress through buying private property as McNally observes as the annihilation of the native by contending their spatial control on the places as indigenous Indians revolted in the War of Independence 1857 in the times of British Empire, indigenous Colombians did it and lost “3000 trade unionists” (McNally, 2006, p. 241) in opposition to the U.S. supported totalitarian administrations. To maintain "Supplies and logistics" of the "ammu" (Hanif, 2018, pp. 19, 22) from the Hanger to the Camp makes Momo a "corporate slave" of a "supply chain" to make the Camp a "tourist destination for foreign people" (Hanif, 2018, pp. 40, 44) to upgrade their "business portfolio" (Hanif, 2018, p. 41) in the international ammo trafficking. In this perspective Said argues that “" "commercial geography," as the connection between national pride in scientific and civilizational achievement and the fairly rudimentary profit motive was urged, to be channelled into support for colonial acquisition" (Said, 2003, p. 219). For Momo, "This is not how distribution of wealth works in post-war economies" in poor countries as it provokes "consumerist urges" (Hanif, 2018, p. 53, 54) demands "buying power" (Hanif, 2018, p. 173) after granting loans to multiply "dollarized profit margins" and free trafficking for their products as to this is "how friendships work. This is how global alliances are formed. This is called team building. This is called Management 3.0" (Hanif, 2018, p. 169) in business. The Reluctant Fundamentalist endorses it when Chengaze observes the authority of "Empire State Building" and "World Trade Center" (Hamid, 2019, pp. 29, 43) in the international trade and politics. From "Maybelline" (Hamid, 2019, p. 79) to Princeton, Chengaze observes her political hegemony emanating from "Multinational corporations" (Hamid, 2019, p. 107), as Spybey maintains that America manages her from economic ascendency maintained through "integrated resources of the global economy" (Spybey, 1996, p.3). In Trespassing Daanish observes market economy and business as all imposing and powerful "business, and that's what corporate America is all about. The best brand. We have the most famous in the world: Coca-Cola, McDonald's, Nike, 
Kodak. And now another: Desert Storm” (Khan, 2013, p. 318). We are in a new international system called "globalisation" (Friedman, 1999). It is no longer the policing of a region or colony. It has become the security of the "entirety" (McNally, 2006, p. 237) of the world market. Iraq war against Saddam on the plea that he has arms of mass destruction is one of the conspicuous examples to state as to how America legitimized her intervention in Gulf. In Trespassing Daanish as a journalist writes about Gulf War that the reconciliation between Iran and Iraq infuriated America and she changed its policy towards Iraq by becoming a foe from friend in the following words that "A name worth noting, War Plan 1002-90. Why the aboutface? It was the same Iraq, the one that had been funded and armed by the US during the war. Mirroring the government's shift, the US media also began to portray Iraq differently. It was no longer an ally. It had become the enemy" (Khan, 2013, p. 147). In this regard, discussing the role of the USA in providing financial aid for Afghanistan and gulf war Labévière's argument becomes pertinent to understand as to from where this money for treacherous proselytism come to finance mosques, Koran schools and Islamists organizations to coordinate war against "impious" Arab-Muslim regimes that organizes European Muslims activism that the "real threat lies elsewhere: in Saudi Arabia and other oil monarchies allied with the United States. The greatest world power is fully aware of this development. Indeed, its information agencies have encouraged it. In certain parts of the world, the CIA and its Saudi and Pakistani homologues continue to sponsor Islamism" (Labévière, 2000, p. 14).

In conclusion, liberal internationalism hinges on the conflict of 'have' and 'have not' and incorporates the theory of development and dependency of the poor nations to encompass its desired aims. It is a utopian dream to have economic equivalence by means of superpowers' sanctioned institutions and approved aids as their economies are dependent upon the poor nations. Hence, this institutionalized supremacy of the well-developed nations identifies that liberal internationalism is inherently colonial. Momo in Red Birds, Chengaze in The Reluctant Fundamentalist and Daanish in Trespasssing are constantly found resisting this branding of their being in the third world nations in their respective situations. Momo invades the Hanger but he finds only the dead body of Bro Ali. Chengaze returns home yet his encounter with the American stranger obfuscates his recognition of a "business card" with the sheen of a "metal" 
(Hamid, 2019, p. 111) gun. Daanish too returns to Pakistan from America after a hopeless journalist practice but remains embroiled in Karachi's political turmoil and international oppression. Momo's incursion in the Hanger, Chengaze and Daanish's return from America to Pakistan manifest deaccession and dispossession of their American identity, but paradoxically, they become the subjects of neo-colonial oppression of war on terror definition of their personhood developed after $9 / 11$.

\section{References}

Andre, Gunder. F. (1969). Latin America:Underdevelopment or Revolution; Essays on Development of Underdevelopment and the Immediate Enemy. Monthly Review Press. Brown, C., and Ainley K. (2009) Understanding International Relations. Palgrave Macmillan. Carr, E.H. (2001). The Twenty Years' Crisis: Introduction by Michael Cox. Palgrave.

Foucault, M. (1972). The Archaeology of Knowledge and the Discourse on Language. New York: Pantheon.

Friedman, T. (1999). Manifesto of the Fast World (New York Times Magazine) https://www.nytimes.com/1999/03/28/magazine/a-manifesto-for-the-fast-world.html accessed 19 May 2019

Hamid, M. (2019). The Reluctant Fundamentalist. Karachi: Oxford University Press.

Hanif, M. (2018). Red Birds. London: Bloomsbury. Hanif, 2018,

Huggan, G. (2001) The Postcolonial Exotic: Marketing the Margins. London: Routledge.

Gershon, I. (2011). Neoliberal agency. Current Anthropology 52 (4), 537-555.

Krishna, S. (2008). 'How does colonialism work?' In Jenny Edkins and Maja Zehfuss (eds.), Global Politics: A New Introduction, $2^{\text {nd }}$ edt. London and New York: Routledge.

Lacan, J. (1968) The Language of the Self: The Function of Language in Psychoanalysis, translated with notes and commentary, by Anthony Wilden, Baltimore, MD: Johns Hopkins University Press.

Khan, Uzma A. (2013). Trespassing. Pakistan: Ilqa Publications.

Labeviere, R. (2000) Dollars for Terror: United States and Islam. New York: Algora Publishing. 
Lenin, V.I. (2004) Imperialism: The Highest Stage of Capitalism. New York: International Publishers.

McClennen, Sophia A. and Alexandra Schulthies Moore. (2016) "Introduction: Aporia and Affirmative Critique: Mapping the Landscape of Literary Approaches to Human Rights Research," The Routledge Companion to Literature and Human Rights. Abingdon: Routledge.

Marx K. (1920). Capital: A Critical Analysis of Capitalist Production, Frederick Engels (eds.). $17^{\text {th }}$ edt. London: William Glaisher Limited.

McNally, D. (2006). Another World is Possible: Globalisation and Anti-Capitalism. Arbeiter: Ring Publishing.

Rist, G. (2008). History of Development: From Western Origins to Global Faith. Zed Books. Said, E. (2003) Orientalism. London: Penguin.

Saleem, Ali U. (2015). Paracolonialism: A Case of Post-1988 Anglophone Pakistani Fiction. $\mathrm{PhD}$ Diss, University of Bedfordshire.

Santos, T. Dos. (2001). Crisis of Development Theory and Problem of Dependence in Latin America, in Henry Bernstein (eds.). Underdevelopment and Development. Palgrave.

Singh, H. (2012). 'Insurgent Metaphors: Decentering 9/11 in Mohsin Hamid's The Reluctant Fundamentalist and Kamila Shamsie's Burnt Shadows' in Ariel. 43 (1). pp. 1-18.

Shamsie, M. (2009) "Covert Operations in Pakistani Fiction." Commonwealth: Essays and Studies, 31 (2), pp. 15-27.

Sadaf, S. (2017). Terrorism, Islamization, and Human Rights: How Post 9/11 Pakistani English Literature Speaks to the World. PhD Diss, University of Western Ontorio.

Spivak, Gayatri C. (1985). The Rani of Sirmur: An Essay in Reading the Archives. History and Theory 24 (3), 247-272.

Spybey, T. (1996). Globalization and World Society, Cambridge: Polity. Stallybrass,

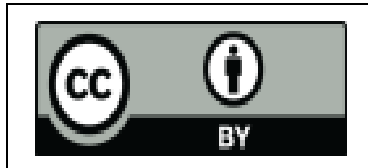

@ 2021 by the author. Licensee University of Chitral, Journal of Linguistics \& Literature, Pakistan. This article is an open access article distributed under the terms and conditions of the Creative Commons Attribution (CC BY) (http://creativecommons.org/licenses/by/4.0/). 